\title{
Solvent-Free Coumarin Synthesis
}

\author{
Teizo Sugino and Koichi Tanaka* \\ Department of Applied Chemistry, Faculty of Engineering, Ehime University, Matsuyama, Ehime 790-8577
}

(Received November 20, 2000; CL-001048)

The synthesis of coumarins via Pechmann and Knoevenagel condensation reactions under solvent-free conditions is reported, in which waste minimization, simple operation and easier product work-up can be achieved.

Coumarin derivatives are important chemicals in the perfume, cosmetic, agricultural and pharmaceutical industries. ${ }^{1}$ However, the conventional methods for coumarin synthesis require drastic conditions. For example, 4-methyl-7-hydroxycoumarin has been prepared by stirring a mixture of resorcinol and ethyl acetoacetate in concd $\mathrm{H}_{2} \mathrm{SO}_{4}$ for $12-24 \mathrm{~h} .{ }^{2}$ The development of alternative environmentally friendly synthetic methods of coumarins is strongly requested. Recently, synthesis of 7-hydroxycoumarin derivatives via the Pechmann reaction catalyzed by solid acid catalysts (e.g., zeolite H-beta) in refluxing toluene has been reported. ${ }^{3}$ The solid base catalyzed synthesis of coumarin-3-carboxylic acids derivatives by Knoevenagel reaction in refluxing toluene has also been reported. ${ }^{4}$ Here, we report a simple and efficient synthesis of coumarins via the Pechmann and Knoevenagel condensation reactions under solvent-free conditions.

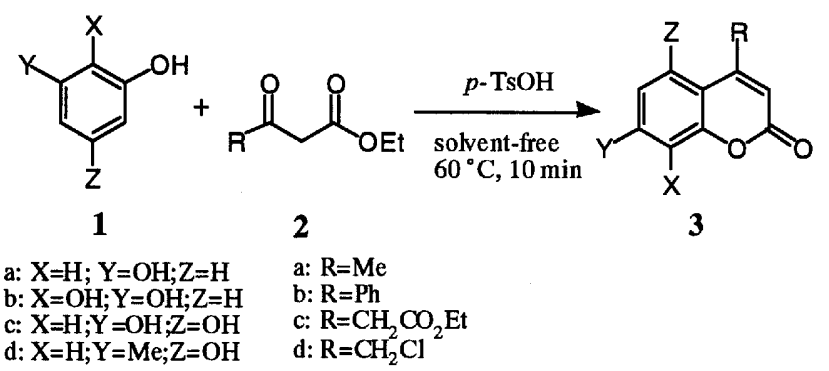

Table 1. Solvent-free Pechmann reactions of phenols (1) and $\beta$-keto esters (2)

\begin{tabular}{ccclllc}
\hline \multirow{3}{*}{3} & $\mathrm{X}$ & $\mathrm{Y}$ & $\mathrm{Z}$ & $\mathrm{R}$ & \multicolumn{3}{c}{ Yield $/ \%$} \\
\hline a & $\mathrm{H}$ & $\mathrm{OH}$ & $\mathrm{H}$ & $\mathrm{Me}$ & 98 & $82-90$ \\
b & $\mathrm{H}$ & $\mathrm{OH}$ & $\mathrm{H}$ & $\mathrm{Ph}$ & 92 & 0 \\
c & $\mathrm{H}$ & $\mathrm{OH}$ & $\mathrm{H}$ & $\mathrm{CH}_{2} \mathrm{CO}_{2} \mathrm{Et}$ & 79 & 40 \\
d & $\mathrm{H}$ & $\mathrm{OH}$ & $\mathrm{H}$ & $\mathrm{CH}_{2} \mathrm{Cl}$ & 0 & 0 \\
e & $\mathrm{OH}$ & $\mathrm{OH}$ & $\mathrm{H}$ & $\mathrm{Me}$ & 69 & 0 \\
$\mathrm{f}$ & $\mathrm{H}$ & $\mathrm{OH}$ & $\mathrm{OH}$ & $\mathrm{Me}$ & 81 & 0 \\
g & $\mathrm{H}$ & $\mathrm{Me}$ & $\mathrm{OH}$ & $\mathrm{Me}$ & 66 & 68 \\
\hline
\end{tabular}

${ }^{\mathrm{a}}$ Ref. 2 and 5.
To an equivalent mixture of resorcinol (1a, $1.1 \mathrm{~g}, 10.0$ mmol) and ethyl acetoacetate $(\mathbf{2 a}, 1.3 \mathrm{~g}, 10.0 \mathrm{mmol})$ was added $\mathrm{TsOH}(0.09 \mathrm{~g}, 0.5 \mathrm{mmol})$ in a mortar and ground well with a pestle at room temperature. The mixture was heated at $60{ }^{\circ} \mathrm{C}$ for 10 min under atmosphere. After cooling, water was added to the reaction mixture and the crystalline products were collected by filtration to give 7-hydroxy-4-methylcoumarin (3a, $1.73 \mathrm{~g}$ ) in $98 \%$ yield. The crude crystals thus obtained were recrystallized from EtOH to give pure 3a as colorless prisms (mp 185-187 ${ }^{\circ} \mathrm{C}$ ). Similarly, solvent-free Pechmann reactions of $\mathbf{1}$ and $\mathbf{2}$ afforded $\mathbf{3 b}, \mathbf{3 c}, \mathbf{3 e}, \mathbf{3 f}$, and $\mathbf{3 g}$ in $92,79,69,81$, and $66 \%$ yields, respectively (Table 1 ). This method is very useful because $\mathbf{3 b}, \mathbf{3 d}, \mathbf{3 e}$ and $\mathbf{3 f}$ have not hitherto been obtained from the reaction in $\mathrm{H}_{2} \mathrm{SO}_{4},{ }^{5}$ however $3 \mathbf{d}$ was not formed either in $\mathrm{H}_{2} \mathrm{SO}_{4}$ or in the absence of a solvent.

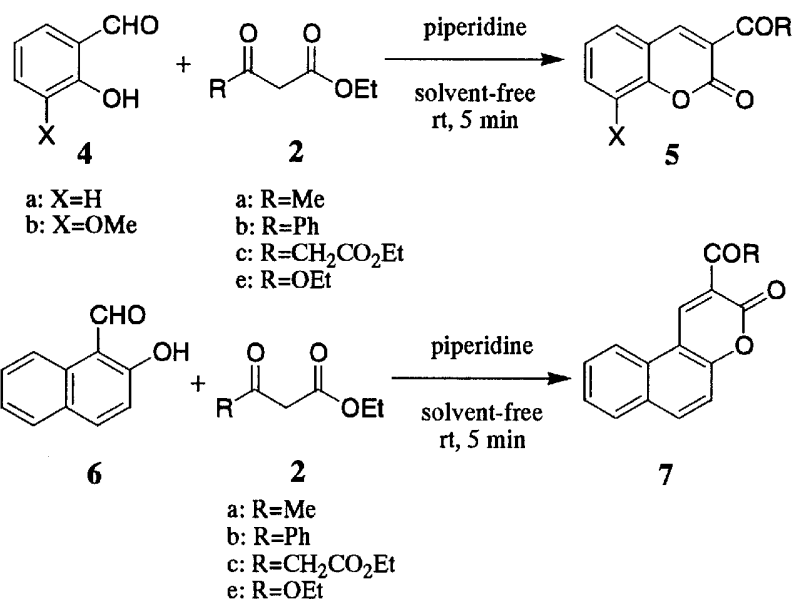

Solvent-free Knoevenagel reactions of salicylaldehydes (4) and $\beta$-keto esters (2) were also found to proceed efficiently and under milder reaction conditions than in EtOH solution. ${ }^{6}$ For example, a mixture of salicylaldehyde (4a, $1.22 \mathrm{~g}, 10.0 \mathrm{mmol})$, diethyl malonate $(2 \mathrm{e}, 1.60 \mathrm{~g}, 10.0 \mathrm{mmol})$ and a few drops of piperidine was mixed and ground well for $5 \mathrm{~min}$ at room temperature. The reaction mixture was neutralized with dil $\mathrm{HCl}$ and then the crystalline product was isolated by filtration to give 3-ethoxycarbonylcoumarin $(\mathbf{5 c}, 2.07 \mathrm{~g})$ in $95 \%$ yield. The crude crystals thus obtained were recrystallized from EtOH to give pure 5c as colorless prisms ( $\mathrm{mp} 94-95^{\circ} \mathrm{C}$ ). Similarly, substituted coumarin derivatives were obtained in high yields (Table 2). When 2-hydroxy-1-naphthaldehyde (6) reacted with $\beta$-keto esters (2) under the same reaction conditions in the absence of a solvent, benzocoumarin derivatives (7) were obtained in high yields (Table 3). Recently, montmorillonite KSF catalyzed Knoevenagel reaction of salicylaldehyde (4a) and diethyl malonate (2e) in the absence of solvent at $160{ }^{\circ} \mathrm{C}$ was found to give $\mathbf{5 c}$ in $44 \%$ yield. $^{7}$

It has been reported that the Knoevenagel reaction of 2- 
Table 2. Solvent-free Knoevenagel reactions of salicylaldehyde (4) and $\beta$-keto esters (2)

\begin{tabular}{llll}
\hline 5 & X & R & Yield /\% \\
\hline a & H & $\mathrm{Me}$ & 99 \\
b & H & $\mathrm{Ph}$ & 97 \\
c & $\mathrm{H}$ & $\mathrm{OEt}$ & 95 \\
d & $\mathrm{H}$ & $\mathrm{CH}_{2} \mathrm{CO}_{2} \mathrm{Et}$ & 73 \\
e & $\mathrm{OMe}$ & $\mathrm{Me}$ & 99 \\
f & $\mathrm{OMe}$ & $\mathrm{Ph}$ & 99 \\
g & $\mathrm{OMe}$ & $\mathrm{OEt}$ & 97 \\
h & $\mathrm{OMe}$ & $\mathrm{CH}_{2} \mathrm{CO}_{2} \mathrm{Et}$ & 91 \\
\hline
\end{tabular}

Table 3. Solvent-free Knoevenagel reactions of 2-hydroxy-1-naphthaldehyde (6) and $\beta$-keto esters (2)

\begin{tabular}{clc}
\hline 7 & $\mathrm{R}$ & Yield $/ \%$ \\
\hline $\mathrm{a}$ & $\mathrm{Me}$ & 92 \\
$\mathrm{~b}$ & $\mathrm{Ph}$ & 93 \\
$\mathrm{c}$ & $\mathrm{CH}_{2} \mathrm{CO}_{2} \mathrm{Et}$ & 98 \\
$\mathrm{~d}$ & $\mathrm{OEt}$ & 97 \\
\hline
\end{tabular}

hydroxy-3-methoxybenzaldehyde (4b) and ethyl cyanoacetate (8) affords 8-methoxy-2-oxo-2 $H$-chromene-3-carbonitrile (9) via intramolecular cyclization of $Z-10$ in $35 \%$ yield under reflux in EtOH. ${ }^{8}$ Very interestingly, however, the condensation reaction of $\mathbf{4 b}$ and $\mathbf{8}$ in the absence of a solvent gave 8-methoxy-2oxo- $2 \mathrm{H}$-chromene-3-carboxylic acid ethyl ester $\mathbf{5 g}$ ) in $65 \%$ yield along with small amount of $\mathbf{9}$ (11\% yield). Compound $\mathbf{5 g}$ might be obtained via hydrolysis of iminolactone $\mathbf{1 2}$ formed by intramolecular cyclization of $E \mathbf{- 1 1}$.

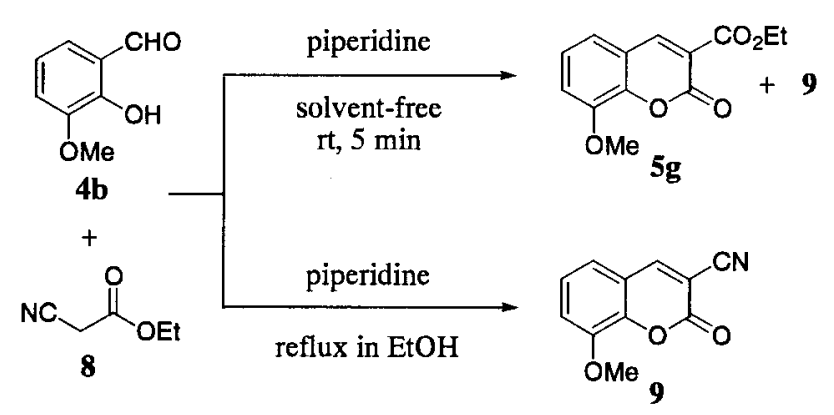<smiles>CCOC(C#N)=Cc1cccc(OC)c1O</smiles><smiles>CCOC(=O)/C=C/c1cccc(OC)c1O</smiles><smiles>CCOC(=O)c1cc2cccc(OC)c2oc1=N</smiles>

In conclusion, this simple solvent-free technique ${ }^{9}$ affords various kinds of coumarin derivatives in excellent yields without forming environmentally harmful waste.

\section{References and Notes}

1 W. C. Meuly, "Kirk-Othmer Encyclopedia of Chemical Technology," 3rd ed., John Wiley \& Sons, New York (1979).

2 E. C. Horning, "Organic Syntheses, Coll. Vol. III," John Wiley \& Sons, New York (1955), p. 281.

3 A. J. Hoefnagel, E. A. Gunnewegh, R. S. Downing, and H. van Bekkum, J. Chem. Soc., Chem. Commun., 1995, 225.

4 A. Ramani, B. M. Chandra, S. Velu, and S. Sivasanker, Green Chem., 1, 163 (1999).

5 S. Sethna and R. Phadke, Org. React., 7, 1 (1953).

6 G. Jones, Org. React., 15, 204 (1967).

7 F. Bigi, L. Chesini, R. Maggi, and G. Sartori, J. Org. Chem., 64, 1033 (1999).

8 E. C. Horning and M.G. Horning, J. Am. Chem. Soc., 69, 968 (1947).

9 K. Tanaka and F. Toda, Chem. Rev., 100, 1025 (2000). 